\title{
MDAI 2015 参加報告
}

\section{成川 康男（桐朋学園）}

\section{1.はじめに}

知的システムに必要とされる意思決定や情報融合に 関するさまざまな側面の最新の研究や応用を紹介し議 論することを目的とし2004年にバルセロナで第 1 回 目を開催した国際会議MDAI（Modeling Decisions for Artificial Intelligence) は，順調に回数を重ね，2015年 には12回目が，スウェーデンのシェブデ(Skövde)で開 催されることになりました. シェブデは, イエテボリと ストックホルムを結ぶ鉄道のイエテボリ寄りにあり, イエテボリから特急列車に乗ると 1 時間程度，ストッ クホルムからは 2 時間程度で着きます. 駅の近くにボ ルボの工場と大学があり, そのシェブデ大学が今回の 会場です. 第 1 回から私と共同でProgram co-chairを やっているTorraさんが，シェブデ大学の教授に就任 したのに伴い, 彼がGeneral Chairも兼任しての開催で す.

最近は, 論文の投稿数は減少傾向にあり, 期限ま でに38の論文が来て, Springerの Lecture Notes in Artificial Intelligenceに掲載が決まったのは18の論文 でした，近年の傾向として，期限に間に合わない，あ るいは, Journalに掲載するためLNAIには載せたくな いなどの理由で, CD-ROM proceedings (実際はUSB) を希望する方々もいて, 実際の投稿数は50近くありま した.

\section{2. 会議について}

会議は, 9:00からのOprning Sessionで始まり, 9:30か ら,ドイツのUniversity of PaderbornのEyke Hullermeier 教授の総合講演から始まりました. Hullermeier 教授は 1967年生まれの比較的若い方ですが，Google Scholar での引用数が 6000 を超えている大物です. 彼の講演の タイトルは, “Preference Learning: Machine Learning meets Preference Modeling”ということで，選好の モデリングと機械学習を融合させた, 彼の提唱する “Preference Learning”についての解説でした. 彼の講 演は，分かりやすいスライドと明快な説明で，そこで は, Agrregetion Operatorやその代表例である Choquet

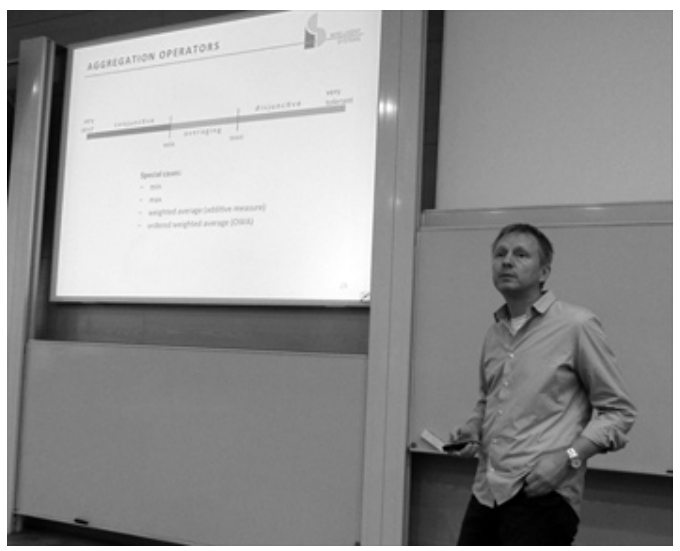

Eyke Hullermeier 教授の総合講演

積分を効果的に応用しており, 大変参考になりました

総合講演の後は, Aggregation Operatorのセッショ ンと, クラスタリングのセッションに分かれてのそれ ぞれの発表です。私は, Aggregation operatorのセッ ションに参加しましたが, 北九州の吉田先生や北海道 の大西先生, そして, 久しぶりにフランスの Labreuche さんの発表が聞けたのは良かったと思いました。

今年は，予算が沢山取れた様で，午後も 2 つの招 待講演がありました。1つは，イギリスのQueen's University BelfastのWeiru Liu教授のGame-Theoretic Approaches to Decision Making in Cyber - Physical Systems Security, もう一つは, フランスのUniversite de Technologie de Compiegne の Thierry Denoeux 教 授の Statistical forecasting using belief functions で す. Liu教授の講演のChair は乾口先生, Denoeux 教 授の講演のChair は私が担当しました. Denoeux 教授 は International Journal of Approximate Reasoningの Editor-in-chief としても知られている方です. 彼は, Likelihood-based belief functionを利用した現実世界 の問題へのアプローチを解説し, 実際のデータを用い て, ベイズ法よりも Likelihoodを用いた方法の方がエ ラーの出現率が小さかったということを示しました. Belief 関数の理論と応用が進んでいることが実感でき ました。 


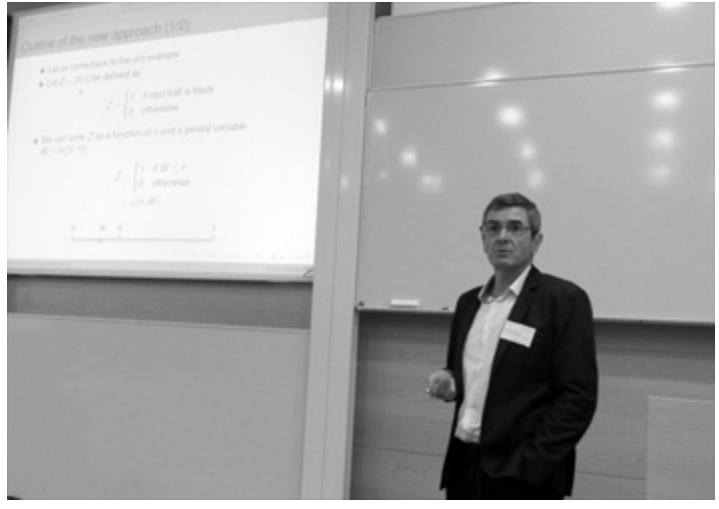

Thierry Denoeux 教授の講演

1 日目の最後は, クラスタリングと Social network の 2 つのパラレルセッション, その後, 市立図書館? の中にあるレストランでの晚餐と続きました.すべて, 駅の近くのため, 徒歩で移動できとても便利でした.

二日目は, 朝 $8: 45$ からパラレルセッションでLogic とComputational intelligence and optimization, その 後, スウェーデンのChalmers University of Technology の Devdatt Dubhashi Classifying large graphs with differential privacyという題での総合講演, 次は, 再度 パラレルセッションでファジィ積分と Computational intelligence and optimizationでした. 昼食後, 総合講演 で,アメリカ合衆国のVanderbilt University のBradley Malin準教授のModeling the Complex Search Space of Data Privacy Problemsでした.

Data Provacyの問題は, Torra教授も中心的にかか わっている問題で, Melin準教授のスライドはとてもわ かりやすく興味を引きました。時間があった私も関わ りたいと思うような内容でした。

この日,早めに終わったのは, Social eventとして,バ スを利用したツアーが用意されていたからでした， ス ウェーデン最大の湖 (EU 最大でもある)であるヴェー ネルン湖の畔にある，スウェーデンの古い城である Läckö Castleにバスで行きそこに隣接するレストラン で晚餐会を開くというものでした．シェブデから距離 はあったと思うのですが，人口密度も小さいためか道 路は空いていて快適にバス内の時間が過ごせました。 私はTorra教授と彼の出した問題を考えているうちに 到着しました. ガイドッアーで城内を見学した後, レ ストランに移動して晚餐会が始まりました。 そこでは, 今年で筑波大を定年になる宮本先生にTorra教授から プレゼントが手渡されました。

3日目は 8:30からパラレルセッションで, Preferenceと Data mining and decision makingでした. 私は, Data mining and decision makingのセッションで, 最近

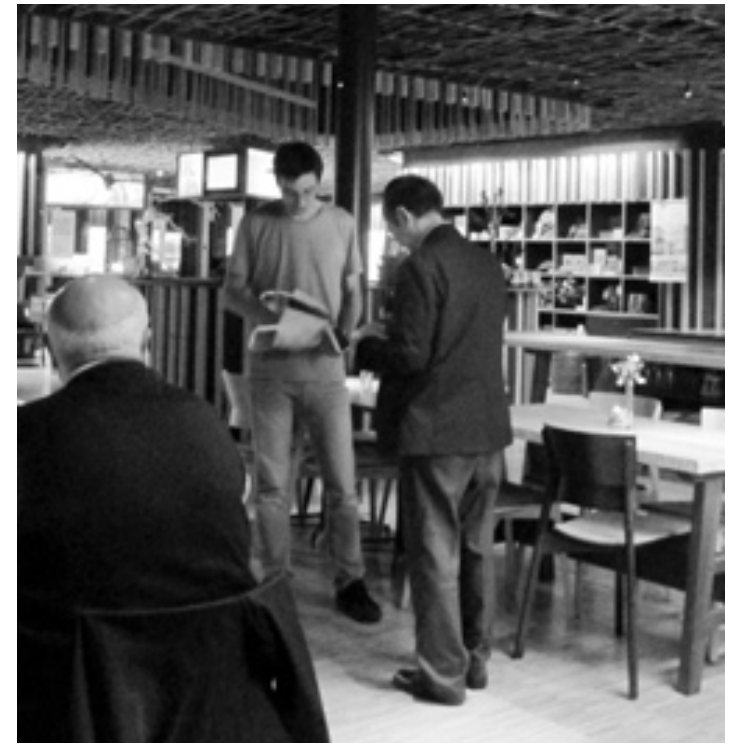

宮本先生への記念品贈呈

注目を浴びつつある,Hesitant fuzzy setsについて発表 しました。

次の時間は，スウェーデンの Karlstad University の Simone Fischer-Huebner 教授の Privacy and Transparency for Decision Making という題目での総合講演, そして，その次はAggregation operatorのセッション があり, 短いClosing ceremony で終了となりました.

\section{3. 最後に}

MDAIの特徴としては，採択数でもわかるように比 較的小規模な国際会議ですが, 関連分野のよく知られ た方々を毎年何名か招待し，その分野のLectureを総 合講演として 1 時間程度していただいています。 大御 所と言われる方々から, 若手の有望な方々までいろい ろな講演がありました。 その講演がもとで, 新たな論 文に発展したものもあります.

MDAIの特徴として, Banquetだけでなく昼食でも会 場をともにし，そこで親睦を深めるといったこともし ています. 毎年参加してくれて顔なじみになった方々 も多く, 彼らの毎年の新しい成果を知るのも楽しみの 一つです.

しかし，12年前と比べてみると，ヨーロッパでは確 実に若い方々が台頭してきていると感じます.彼らが, ファジィ測度のようなすぐに実用に結びつかないもの を，あきらめず，うまく利用しながら何とか応用につ なげていこうという姿勢が見えるような気がします. 日本の若手の方々も是非このような国際会議に参加し て, 視野を広げていただきたいと思って言います。 
なお，総合講演の要旨とスライドは http://www.mdai.cat/mdai2015/

にあるので参考にしていただくとよいと思います．

次回のMDAIは 9 月19日から21日までフランスとス ペインの国境にある小国アンドラで開催される予定で す.アンドラはバルセロナからバスが便利と聞いてお ります. 日本からも多くの方々が参加されることを願つ ております。詳細はhttp://www.mdai.cat/mdai2016/ をご覧ください．これが掲載される頃はLNAIのため の締め切りは過ぎてしまっているかもしれませんが, CD-ROM Proceedings と発表でしたら, 締め切り後
でもご相談に乗れると思います，なお，問い合わせの メールアドレスはmdai@mdai.catですが，日本語で大 丈夫です.

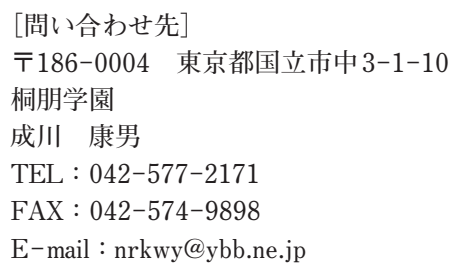

